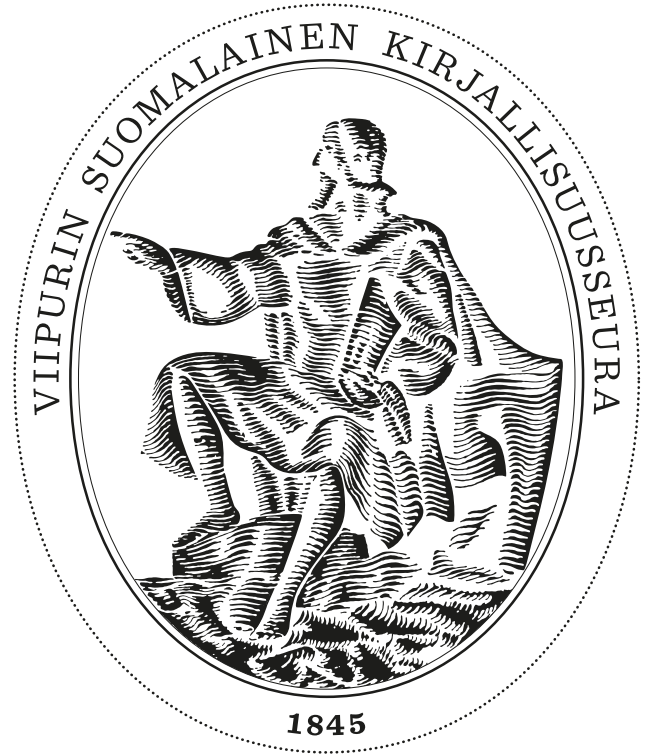

VIIPURIN SUOMALAISEN

KIRJALLISUUSSEURAN

TOIMITTEITA

(18)

Muuttuvien tulkintojen Viipuri 
Kansikuva: Osa Severin Falkmanin vuonna 1886 tekemästä öljymaalauksesta Kaarle Knuutinpoika Bonde lähdössä Viipurin linnasta Tukholmaan kuninkaanvaaliin 1448. Karl Knutson Bonde på väg från Viborgs slott till kungavalet i Stockholm 1448.

Kansallisgalleria/Kirsi Halkola. Ateneumin taidemuseo.

Viipurin Suomalaisen Kirjallisuusseuran Toimitteita osa 18 Muuttuvien tulkintojen Viipuri

Toimittaneet:

Anu Koskivirta (osan päätoimittaja),

Pentti Paavolainen (sarjan päätoimittaja),

Sanna Supponen (sarjan toimitussihteeri)

Kuvatoimitus:

Risto Marjomaa

Graafinen suunnittelu \& taitto:

Eemeli Nieminen, www.eemelinieminen.fi

ISBN: 978-952-67216-3-7 (Toimite 18, PDF)

ISSN: 1236-4304 (Sarja)

Painettu: 2016, Juvenes Print

Painosmäärä: 200 kpl

2. korjattu painos.

Julkaisija: Viipurin Suomalainen Kirjallisuusseura, Helsinki 


\section{Ernst Löfström (1865-1937): unohdettu Viipurin valtaaja}

\section{PRIIMUS JA HOVIKEIKARI}

Sisällissodan viimeinen suurtaistelu sekä punaisen ja valkoisen terrorin huipentumat mahtuivat Viipurissa muutamille neliökilometreille ja muutamiin kevätpäiviin ja -öihin. Loppurytäkkä ei sujunut millään muotoa laskelmoidusti ja ennustettavasti. Sattuma ohjasi sekä yksilöiden että massojen kohtaloita. Valtausdraaman yksi sivujuoni haarautui valkoisten voittajien mieskohtaisesta vihanpidosta.'

Ylipäällikkö Carl Gustaf Emil Mannerheim ja Itäarmeijan komentaja Ernst Löfström olivat kollegoja ja lähes ikätovereita, mutta muuten eri muoteista valettuja. He olivat tutustuneet jo poikasina 1880-luvulla Haminan kadettikoulussa. Löfström valmistui priimuksena ja Mannerheim sai potkut koheltamisen ja kurittomuuden vuoksi. Aikuisiän kanssakäymiseen lienee vaikuttanut Haminan muisto: toverikurin säännöstö soi Löfströmille oikeuden ja velvollisuuden piiskata pyllylle tulevaa marsalkkaa.

Pietarin sotaopistoissa he pyörivät samassa pienehkössä piirissä. Löfström saavutti upseerinarvonsa ensin, mutta Mannerheimkaan ei enää ollut surkimus vaan varteenotettava kilpailija. Ystäviä heistä ei todellakaan tullut. Löfström koki Mannerheimin uran nousevan muista kuin sotilaallisista ansioista. Ratsastustaidot ja komea ulkonäkö painoivat valtteina hovin liepeillä. Löfström yleni itsekin hyvin ja pääsi arvostettuun henkikaartin Semjonovin rykmenttiin. Silti hänen painamattomat muistelmansa hohkaavat kateutta, kaunaa ja pahantahtoisuutta.

Viipurilaissyntyinen Löfström oli Saimaan kanavan päällikön poika ja hyvästä upseerisuvusta, mutta ei aatelinen. Esi-isien ja verkostojen puute haittasi etenemistä aristokraattisessa keisarikunnassa. Mannerheim puolestaan oli suurta, joskin köyhtynyttä sukua. Hän sai korkeiden tuttavuuksiensa kautta avustusta tsaarittaren käsikassasta. Raha jyrkensi uran nousua. Taka-alalle jäivät ahkerammat ja lahjakkaammat suomalaiset. Heillä ei ollut varaa upeisiin univormuihin, jotka eliittiyksiköissä piti kustantaa itse.

Mannerheim esiintyi edukseen paraateissa ja kunniavartioissa, meni rikkaisiin naimisiin ja keikaroi ylimysten suosikkina. Samaan aikaan Löfström jatkoi 
pedanttina lukutoukkana. Hän uurasti kirjastoissa ja kasarmeilla. Tarkka-ammunnassa hän kehittyi kilpailutasolle. Erilaisia taitoja ei punnittu tarpeeksi oikeudenmukaisissa kisoissa. Löfströmillä kävi ensimmäinen huono tuuri vuonna 1905. Hän päätyi likaisiin töihin kukistamaan Pietarin vallankumouksellisia. Mannerheim sai kunniakkaampaa kokemusta Kaukoidässä. Löfström pärjäsi katutaisteluissa ja puhdistuksessa, mutta tehtävät eivät olleet yhtä mieltäylentäviä kuin kilpailijan ratsastus halki Aasian. ${ }^{2}$

Löfström ja Mannerheim ajautuivat vihamiehiksi viimeistään maailmansodan alussa palvellessaan samalla rintamaosalla. Onni suosi Mannerheimia Hodel-virralla 15. elokuuta 1914. Ratkaisuhetkillä hän hidasteli ratsuväkineen tietymättömissä, mutta sitä ei huomannut kukaan. Löfströmin johtama jalkaväki löi itävaltalaiset yksin. Raportit kuvasivat tapahtumia väärin ja Mannerheimin osuutta ylistellen.

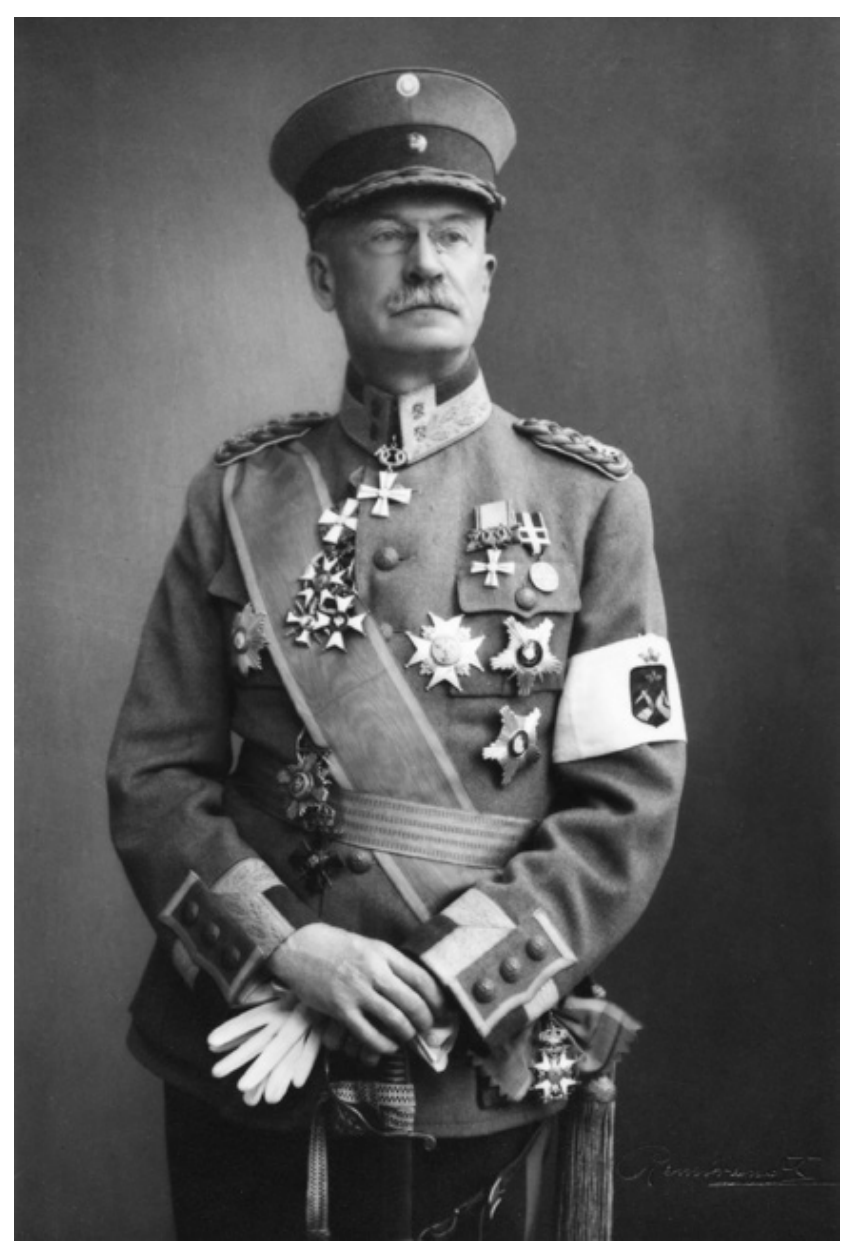

Kenraaliluutnantti Ernst Löfström vuoden 1925 tienoilla lukuisien kunniamerkkiensä kanssa.

Myöhemmässä Opatovin taistelussa Mannerheimin suoritus oli Löfströmin mielestä säälittävä (ynklig). Kentällä tapahtui "tyypillinen teurastus, jossa osapuolet iskivät vastatusten tietämättä tarpeeksi vahvuuksista ja asemista”. Löfströmin jalkamiehet sattuivat olemaan edullisesti metsänreunassa ja tulittivat itävaltalaiset hajalle. Onni vain ei kääntynyt. Mannerheim ei taaskaan joutunut töppäyksistään vastuuseen, päinvastoin, tuttavuuksiensa tai itsekorostuksensa vuoksi hän sai korkeimman kunniamerkin, Yrjön ristin.

Puolan rintamalla Löfström kantoi vastuuta Varsovan puolustajana, mutta tsaarinarmeija sai selkäänsä saksalaisilta ja joutui vetäytymään yhä syvemmälle. Hän sai siirron Itävalta-Unkarin vastaiselle rintamalle ja osallistui kenraali Aleksei Brusilovin suurhyökkäykseen, joka lupaavan alun jälkeen tyrehtyi verilöylyihin. Löfströmin rykmentti tuhoutui lähes jäljettömiin Stochod-virran taistelussa heinäkuussa 1916. Se oli tuskin hänen oma vikansa. 
Mannerheim pärjäsi paremmin, ei älykkyytensä ja urheutensa vuoksi vaan siksi, että sattui saamaan siirron Romanian rintamalle pois ylivertaisten saksalaisten tieltä. Armeijakunnan komentajana Mannerheim joutui lujille, mutta kurjemminkin olisi voinut käydä. Onnettaren suosikki sattui olemaan lomalla silloin kun rivimiehet ryhtyivät erottamaan ja telottamaan päällystöä.

Kenraalimajuri Löfström johti elokuussa 1917 jo divisioonaa, mutta nälkäisenä ja kurittomana siitä ei ollut mihinkään. Valta luisui räyhäävien sotamiesten neuvostoille. Koko armeijan hajotessa hän etsiytyi Suomeen ja valkoisten sotavalmistelujen ytimeen. Samankaltaisesti mutkitteli Mannerheimin sotapolku. Tsaarinarmeijan suomalaisupseereille sisällissota tuli taivaan lahjana. Koskaan ei saada tietää, missä he olisivat ratsastelleet ja patsastelleet ilman tilaisuutta kauan sitten jättämässään syntymämaassa. ${ }^{3}$

\section{KOLOSSAALINEN PALVELUS}

Mitä tärkeimmässä neuvottelussa Vaasassa 25. tammikuuta 1918 Löfström oli eri mieltä kuin Mannerheim, Hannes Ignatius ja Gösta Theslöf. Nämä tahtoivat kukistaa kaupungin venäläisvaruskunnan ylläköllä ja ottaa aloitteen koko maakunnassa. Löfström piti suojeluskuntien alivoimaa selviönä ja riskiä mielettömänä. Hän yritti lykätä aloitusta. Muut suojeluskuntia kokoavat tsaarinupseerit olivat toista mieltä. "Kyllä on pirullista, että jos tässä maassa jotakin koetetaan aikaansaada, on aina henkilöitä, jotka viisastelemisellaan sen estävät”, Ignatius raivosi. ${ }^{4}$ Toiminnan miehet voittivat. Löfströmin mielipide hävisi ja vaikutti naurettavalta Pohjanmaan vaivattoman aseistariisunnan jälkeen.

Löfström kärsi sodan alusta saakka väheksynnästä ja salajuonista. Tehtävät eivät vastanneet kenraalimajurin arvoa ja vankkaa sotakokemusta. Kaikkein kavalimpana kampittajanaan hän piti päämajoitusmestari Ignatiusta. Sekin eripura oli vanhaa perua. He olivat asuneet Pietarissa naapureina ja riitaantuneet jo 180o-luvun puolella miehisestä mustasukkaisuudesta; molemmat tavoittelivat samaa naista, jonka Ignatius nappasi puolisokseen.

Löfström panetteli ammoista ja nykyistä kilpailijaansa tilaisuuden tullen, mutta päämajoitusmestarina Ignatius oli nyt Mannerheimin lähin mies ja pääsi niskan päälle. Vähemmän henkilökohtaisista syistä Löfström karsasti Gösta Theslöfiä, joka kipusi talvella 1918 yleisesikunnan päälliköksi, vaikkei aiempi ura ollut kovin loistokas. Theslöf esiintyi "saksalaisempana kuin saksalaiset itse" ja yritti unohtaa käyneensä omat sotakoulunsa Venäjällä ja Suomessa opettaneensa venäjää lyseossa. Jääkäreiden käsitys korkeiden tsaarinupseerien keskinäisistä sympatioista ei missään nimessä pätenyt yleistyksenä.

Valkoisella armeijalla ei sentään ollut varaa jättää käyttämättä kenraalimaju- 
ri Löfströmin tasoista ammattilaista. Hän sai komentaakseen Savossa muodostuvat joukot. Miksi juuri tänne, hän ajatteli ja oli kieltäytyä huonon suomensa vuoksi. Miesaines oli täysin kouluttamatonta, eikä päämajasta liiennyt muita varustetoimituksia kuin yksi kenttäkeittiö. Silti Löfström onnistui 21. helmikuuta kukistamaan Varkauden punaisen saarekkeen.

Tärkeä menestys varmisti Savon radan ja valkoisten selustan, mutta Löfström ei saanut mitään laakereita. Kuinka ollakaan, Vaasan senaatti kiitti valtauksesta Mannerheimia. Vihamies Ignatius mainitsi myöhemmin, että Varkaudessa Löfström tahtoi teloittaa joka kolmannen vangin, minkä everstiluutnantti Carl Vilhelm Malm esti. Varkaus puhdisštui joka tapauksessa suhteellisesti verisemmin kuin yksikään toinen paikkakunta.

Savon rintaman komentajana Löfströmin menestys jatkui maaliskuussa melko vaatimattomana. Hän saavutti paikallisia pikkuvoittoja, mutta ei tehnyt strategisia aloitteita. Enimmäkseen hän pysytteli puolustuskannalla valittaen materiaali-ja miespulaa, aiheestakin. Yhteistyö suomenkielisten suojeluskuntalaisten ja jääkärien kanssa sujui odotetun hankalasti. ${ }^{5}$

Tampereen kukistuttua 6. huhtikuuta Mannerheimin päämaja käänsi katseensa itään. Kannaksella valkoiset olivat kolme kuukautta sinnitelleet vähillä mies- ja materiaalivahvistuksilla. Nyt prioriteetit vaihtuivat. Kansanvaltuuskunta oli saksalaisten tieltä paennut Viipuriin. Sodan loppunäytöksen paikka oli selvillä. Kannakselle keskittyvän valkoisten Itäarmeijan mielissä takoi iskulause: viimeinkin on Viipurin vuoro!

Itäarmeija oli mieslukuisa ja kohtalaisesti koulutettu ja varustettu. Uupuneiden ja demoralisoituneiden punikkien lyömisestä tuskin oli epäilystä. Viipurin valtaajaa ja kuoliniskun antajaa odotti silti kuolematon kunnia. Kenelle se kuului?

Nuori jääkäriupseeri Aarne Sihvo oli noussut Karjalan rintaman päälliköksi helmikuussa omavaltaisesti. Karjalaislähtöisenä, suomenkielisenä ja ylipäätään karismaattisena hahmona hän hyödynsi kansansuosiotaan. Päämaja tarjosi Karjalaan ruotsinkielistä tsaarinarmeijan everstiä Herman Wärnhjelmiä, mutta hän ei kelvannut. Suojeluskuntalaisten uhkailun ja agitaation takia Sihvo oli pakko valita. Näin siitäkin huolimatta että kilpailijat pitivät häntä röyhkeänä kakarana, jonka preussilainen jääkärikoulutus oli lopullisesti pilannut. ${ }^{6}$

Aarne Sihvo aloitti tehtävänsä kapteenin arvoisena ja muodolliselta koulutukseltaan pelkkänä poikasena. Rintaman johdossa hän pärjäsi hyvin eritoten Vuoksen sillanpään ja Ahvolan polttopisteen puolustajana. Punaisten maakunnallinen ylivoima ei riittänyt rintaman puhkaisemiseen eikä taivuttamiseenkaan. Sihvon maine nousi kohisten ansioista ja propagandasta. Itä-Suomessa hänestä korottui heimopäällikkö. Kieliseikan ja iän puolesta hän oli Mannerheimia sytyttävämpi sankari. Sihvo oli maanlaajuisestikin varteenotettava kil- 
pailija, koska hänessä kirkastui jääkäreiden rooli ryssänupseereihin nähden. Psykologisesti ajatellen Viipurin vapauttaminen oli Sihvon heiniä: palkinto alivoimaisena sinnittelyn kuukausista ja suosionosoitus Karjalan kansalle.

Sihvo ei päässyt valtausarmeijan keulakuvaksi. Hän jäi sivummalle sillä muodollisella perusteella, ettei alle 30-vuotiaana olisi selvinnyt kokonaisen armeijan suunnittelu- ja esikuntatöistä. Mannerheimin ja Sihvon muistelmissa käänne selitetään järkeväksi ja sopuisaksi, mikä ei vastaa aikalaistunnelmia.

Vastoin syvien rivien ääntä ja odotuksia Itäarmeijan komentajaksi nousi kenraalimajuri Ernst Löfström. Nimeä ei moni ollut Kannaksella kuullut - sikälikään, että hän rintamantakaisten omaisten suojelemiseksi käytti äitinsä sukunimeä Toll. Löfström oli kaukana heimopäällikön muotista: ruotsinkielinen 52-vuotias tsaarinarmeijan veteraani.

Miksi Mannerheim valitsi Itäarmeijan komentajaksi vanhan vihamiehensä, josta muut upseerit ja rivimiehet eivät pitäneet?

Everstiksi pikaylennetty Sihvo piti ohittaa jollakulla, eikä kenraalitasolla ollut kovin monia vaihtoehtoja. Löfström oli turvallinen Viipurin valtaaja sikäli, että suomea osaamattomana ja muutenkin etäisenä hahmona hänestä ei voinut sukeutua äkisti kansallissankaria ainakaan siinä merkityksessä kuin Sihvosta. Mahdollista on sekin, että Mannerheim ihmistuntemuksellaan käsitti, etteivät Löfström ja Sihvo missään olosuhteissa löydä toisiaan liittolaisina häntä itseään vastaan.

Löfström sai suuresta tehtävästään tiedon Pieksämäen asemalla. Hän odotti aamuyöllä ylipäällikön junaa, joka saapui monta tuntia myöhässä. Mannerheim oli pahantuulinen ja ilmaisi vielä tyytymättömyyttä Savon rintaman tapauksista, mutta se ei vaikuttanut enää nimitykseen. Löfström saisi vallata Viipurin.

Mannerheim ja Löfström eivät lähentyneet valinnan varmistuttuakaan. Keskustelu sujui yhtä töykeästi kuin ennenkin. Löfström kanteli Ignatiuksen juonittelusta. "En minä ole mikään lapsi”, Mannerheim keskeytti. Kannaksen suurhyökkäyksen kaava oli jo selvillä: Pietarin päärata poikki ja sitten Viipurin kimppuun, punaisten päävoimien murskaaminen mielellään jo ennen linnoitusvyöhykettä kaupungin edustalla. Mannerheim kysyi, mitä aiot tehdä läpimurron jälkeen. Olipa typerä kysymys, Löfström ajatteli ja vastasi vähän omituisesti: en minä sitä voi etukäteen päättää.

Kun Mannerheim ja Löfström nauttivat päivällistä Mikkelin Seurahuoneen salissa, maailmansodan voittojen ja tappioiden muistelu päättyi seurueen kiusaantuneeseen köhähtelyyn. Sanaharkka syntyi akuutimmasta kysymyksestä. Löfström ei tuntenut ylipäällikkönsä mielenliikkeitä tai ärsytti tahallaan. Missä liemessä nyt olisimmekaan ilman saksalaisten apua, Löfström päivitteli. Mannerheim kimpaantui, koska oli raskain uhrein kiirehtinyt Tampereelle 


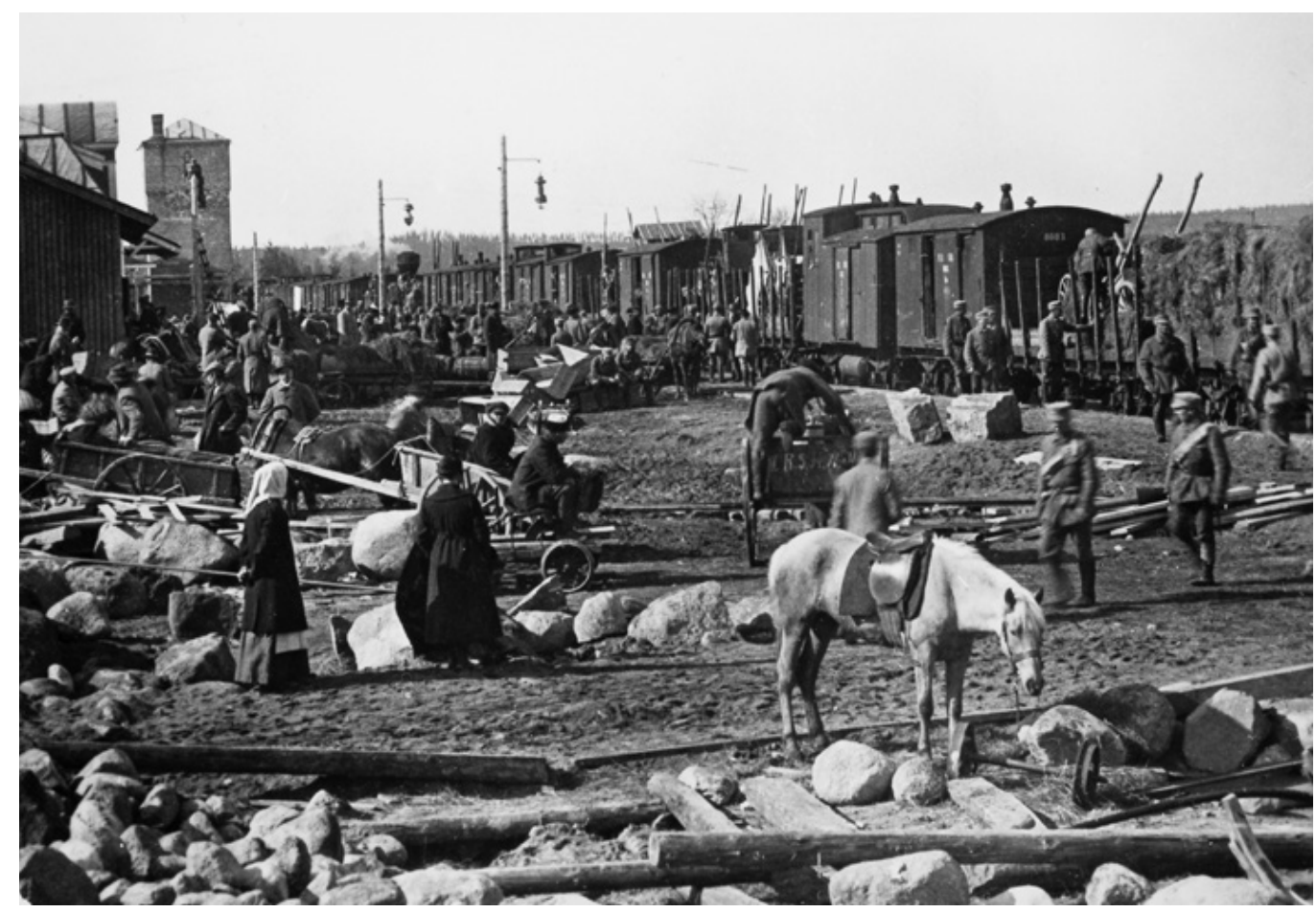

Valkoisten joukkoja valmistautumassa Viipurin valtaukseen Kiviniemessä huhtikuussa 1918.

juuri tätä vaikutelmaa kumotakseen ja suomalaisten kunniaa kirkastaakseen. ${ }^{7}$

Muodollinen sopu oli pakko saada aikaan. Suopeudenosoituksena Mannerheim myönsi Löfströmille 2. luokan vapaudenristin Varkauden valloituksesta, vaikka siitä oli vierähtänyt jo puolitoista tapahtumarikasta kuukautta.

Vaarallisin kiukku ei poltellut päämajassa vaan Karjalan rintamalla. Miksi taivaan tähden Löfström eikä maakunnan oma poika Sihvo! Suomenkieliset olivat näyttäneet voimansa helmikuussa eversti Herman Wärnhjelmin syrjäyttämisessä. Nyt tekeillä oli kapinaliike Löfströmiä, vielä vastenmielisempää ryssänupseeria vastaan. Protestit kantautuivat Vaasan senaattiin. Pääministeri P. E. Svinhufvud lähetti Mannerheimille kirjeen, jossa tähdensi johtajakysymyksen poliittisia ja psykologisia ulottuvuuksia. Senaatin näkemyksen mukaan Ernst Löfström oli joukkojen keskuudessa "ei-toivottu persoona", joka piti korvata Sihvolla.

Kansansuosio oli kuitenkin valintaperusteena toisarvoistunut huhtikuuhun 1918 tultaessa. Valkoisten ei tarvinnut punikkien tavoin huutoäänestää päälliköistään. Kasassa oli oikea armeija, joka tottelisi sitä, jota sen totella käskettiin. Sihvokin alistui asemaansa. Mannerheim ei taipunut senaatin edessä eikä ottanut määräyksiä siviileiltä. Ylipäällikkönä hän varjeli auktoriteettiaan. Kun senaattorit Svinhufvud, Heikki Renvall ja Aleksander Frey saapuivat 15 . huhtikuuta Mikkelin päämajaan, Mannerheimilla oli kilpenään Sihvon us- 
kollisuudenvakuutus. Se riitti. Löfströmin valinta oli tapahtunut tosiasia eikä muuttunut miksikään. Itäarmeijan esikuntapäälliköksi tuli riikinruotsalainen Axel Rappe. Sotatieteellisten opintojensa vuoksi häntä kehuttiin valkoisten "parhaaksi pääksi", vaikka karaktäärissä piili tiettyjä heikkouksia.

Mannerheim vastasi ylipäällikkönä Viipurin suurhyökkäyksestä niin kuin koko sodasta. Itäarmeijan komentajalle kimalsi silti glooriaa. Mannerheim sanoi 1930-luvun julkaisemattomassa haastattelussa, että katsoi tehneensä Löfströmille "kolossaalisen palveluksen".

Sihvo ei ollut ainoa karjalainen, joka menetti Viipurin valtaajan kunnian. Entisen Karjalan Armeijakunnan ydin jäi toistaiseksi paikalleen Ahvolaan, eivätkä Raudunkaan voittajat päässeet rynkyttämään Viipurin portteja ensimmäisinä. Kärjessä kulkisivat uudet vahvistukset. Tehtävänjako kuulosti kummalliselta sikälikin, ettei se hyödyntänyt Sihvon alaisuudessa taistelleiden viipurilaisten kaupunkituntemusta.

Sihvo ei kiukutellut Mannerheimille, mutta sitä enemmän Löfströmille. Vanha tsaarinupseeri oudoksui ensi tapaamisesta saakka heimopäällikköä, joka "esiintyi kuin talonpoika" ja käytti epäkohteliasta kieltä. Sihvo pyysi anteeksi yhtä loukkausta, mutta jatkoi siihen malliin, että Löfströmin huomautteli "pikkumaisesta ja lapsellisesta käytöksestä”.

Ainut kysymysmerkki nousi Venäjää tai maailmansotaa kenties järisyttävistä ulkopoliittisista yllätyksistä. Viipurin kukistumista ei epäillyt kukaan. Voitto itsekseenkin hajoavia punakaarteja vastaan oli varma. Löfström ei silti kiitellyt ylipäällikköä "kolossaalisesta palveluksesta”. Hän vaikutti epävarmalta ja jahkailevaiselta, Mannerheim mietti, melkein kuin sodan aattona, jolloin lopputulos oli oikeasti korkeimman kädessä. ${ }^{8}$

\section{KOLOSSAALINEN KURIRIKKOMUS}

Itäarmeijan suurhyökkäys Kannaksella käynnistyi 20. huhtikuuta. Kaikki sujui suunnitelman mukaan ja joutuisamminkin. Päärata katkesi parin päivän kuluttua. Punaiset romahtivat kautta linjan. Pian oli Viipuri saarroksissa. Turha hätiköinti maksoi valkoisille melkoisesti kaatuneita kaupungin edustalla. Maanalainen suojeluskunta nousi vastarintaan vähän etuajassa ja joutui antautumaan. Kokokuvaa nämä seikat eivät muuttaneet. Sota oli loppumaisillaan. Jännitystä liittyi toki esimerkiksi lopputilityksen luonteeseen. Punainen terrori roihusi Viipurissa. Kosto kyllä kourisi pikimmiten. Valtauksen aattona Löfström julkisti Itäarmeijan päiväkäskyssä, että ase kädessä tavatut tai vastaan hangoittelevat venäläiset sai ampua yksintein. He olivat "lain ulkopuolella" ja vapaata riistaa pikakostolle. ${ }^{9}$ 
Löfström siirsi 27. huhtikuuta Itäarmeijan esikunnan Antreasta Taliin kymmenen kilometrin päähän kaupungista. Sieltä näki ja kuuli kaiken tarpeellisen, ja yhteydet hyökkäyskiiloihin varmistuivat. Mutta ratkaisu oli omavaltainen. Itäarmeijan komentajalla ei ollut oikeutta muuttaa ilman lupaa. Välimatka venähti Mikkelin päämajaan. Mannerheim kiiruhti Antreaan, muttei saanut kiinni Taliin ehtinyttä esikuntaa. Hän tuohtui periaatekysymyksestä: kenraalimajuri, joka on työskennellyt vuosikymmeniä samassa armeijassa kuin minä, ei tiedä, että esikunta siirtyy vain ylipäällikön käskystä!

Löfströmin mielestä haukku ryöppysi hermoilusta ja arvostelukyvyttömyydestä. Mannerheimilla ei ollut mitään työtä Viipurin piirityksessä. Hän yritti tehdä itsensä tärkeäksi ja häiritsi niitä upseereja, jotka valvoivat karttojen ääressä. Mannerheim lähti Antreasta jälleen Mikkeliin toimittamaan jotain ja vakuutti palaavansa Viipuria kukistamaan. Herra varjele, kunpa hän myöhästyisi, Löfström toivoi.

Alaisista koitui Löfströmille pahempia ikävyyksiä. Hän oli muuttanut käsitystään ruotsalaisesta esikuntapäälliköstään Axel Rappesta: "Taitava miekkonen, mutta täysi alkoholisti". Voitonvarmuuden rentouttama Rappe joi Viipurin edustalla häpeilemättä. Sotakorkeakoulun tiedoista täysi "paras pää" ei pysynyt selvänä yhtään piiritys- ja valtauspäivää.

Loppurynnäkkö yöllä 29. huhtikuuta ei kärsinyt Rappen tilasta, koska punaiset olivat jo viimeisen taistonsa taistelleet. Valkoiset juoksivat kantakaupunkiin läpi tyhjentyneiden linjojen. Punaiset yrittivät paeta länteen kohti Haminaa, mutta tuhoutuivat Merijoen pelloille Naulasaaren tienristeyksen tienoolle. Läpimurtoyrityksen torjuivat Aarne Sihvon joukot, jotka jäivät syrjään varsinaisesta valtauksesta.

Löfströmin muistiinpanoissa ja päiväkirjoissa kriittisimmät hetket kuvataan eri tavalla kuin painetuissa sotahistorioissa. Kumma kyllä, Itäarmeijan komentaja nukkui yönsä ja heräsi Talissa 29. huhtikuuta kello 7.20 kuin mihin tahansa työpäivään. Suunnilleen yhtäaikaisesti tulivat tiedot Naulasaaren läpimurtoyrityksen torjumisesta ja kantakaupungin kukistamisesta. Hurraa! Kiitos ja kunnia! Itäarmeijan komentamiseen ei nyt tarvittu muita sanoja.

Löfström lähetti muutaman sähkeen. Sitten hän matkasi aamuhumalaisen esikuntapäällikkönsä Rappen ja muutaman luottoupseerin kanssa kaupunkiin automobiililla. Se juuttui liejuun ja tarvitsi neljän hevosen ja 20 miehen kiskonta-apua. Viivästysten jälkeen seurue oli Viipurissa. Löfström etsi hotelli Kareliasta turhaan kenraalimajuri K. F. Wilkmania, jonka hyökkäyskiila oli kaupungin ottanut. Upseerit kuljeskelivat missä lie. Siviilit kiiruhtivat Löfströmin luokse sitä innokkaammin. Löfström tapasi vanhan ystävättärensä Agnes Lucanderin ja sai kolme suukkoa. ${ }^{10}$ 
Samoilla hetkillä valkoiset toimeenpanivat vallien välissä Suomen historian suurimman joukkoteloituksen. Surmansa sai yli 200 venäläistä, monet erehdyksessä. Valloittajat olivat paljolti pohjalaisia ja kainuulaisia, jotka eivät ymmärtäneet vanhan kaupungin sykettä. Heitä kuitenkin johtivat jääkäriupseerit ja riikinruotsalainen majuri Martin Ekström, joiden päätökset eivät voineet olla satunnaisia. Ennätysteloituksen todennäköisesti siunasi kenraalimajuri Wilkman, joka muutaman päivän kuluttua kommentoi sähkeitse päämajaan: "Ainahan kun suuria töitä tehdään, pikku vahinkoja sattuu"."

Pikku vahingon tapahtumisen aikoihin Löfströmille järjestyi ateria Seurahuoneella. Pidemmät juhlat eivät käyneet päinsä. Itäarmeijan esikunta oli vielä Talissa ja komentajan piti palata sinne. Löfström ja sammunut Axel Rappe olivat perillä kello 22-23:n maissa.

Rappe elpyi aamulla ja jatkoi putkeaan. Hän haastoi riitaa ylempien ja vertaisten kanssa. Aarne Sihvolle hän solkkasi, että hittoako siellä lännessä kuhnailitte, kun me valloitimme kaupunkia. Julkisuuteen levisi Rappen "päissään ja harhaisena" lähettämä sähkösanoma, jossa hän kerskaili suunnitelleensa ja johtaneensa valtausoperaation. Tieto kävi täydestä Ruotsin lehdistössä, joka tahtoi uskoa oman pojan panokseen. Tosiasiassa Rappe ei pystynyt edes allekirjoittamaan raportteja sotatoimista. Löfström kiitti taivasta siitä, että sodankäynti oli jotenkin sujunut moisen oikean käden kanssa. Varamies kapteeni Hällén vajosi melkein samaan kuntoon. Löfström pysytteli selvänä ja sydämistyi alaisiinsa, muttei pystynyt heitä ojentamaan. Alkoholi laski ihmishengen arvoa, joka ei korkealla kieppunut muutenkaan. Valkoisten keskinäisen veljeyden säilyminen tuhansien asemiesten viinanhuuruissa olisi edellyttänyt historian äärimmäistä poikkeustapausta ja ihmettä. Sitä ihmettä ei tapahtunut, niin kuin Toivo Kuulankin kohtalosta tiedetään.

Ernst Löfströmiä ei masentanut ennätysteloitus, mutta muista syistä hän putosi suurtaistelun häviäjien joukkoon. Seurahuone oli vapunpäiväksi siivottu Kuulan kuolemaksi koituneista edellisillan tulimmaisista juomingeista. Nyt oli paljon hienomman juhlan vuoro. Sali täyttyi upseereista, Viipurin silmäätekevistä ja muista kutsuvieraista. Löfström myöhästyi vähän ja etsi tungoksessa paikkaansa arvokkaimmasta pöydästä. Varmaankin Itäarmeijan komentaja oli plaseerattu ylipäällikön oikealle puolelle. Ei, siinä istui iäkäs kenraali August Langhoff. Löfström puskeutui vasemmalle, mutta sitä paikkaa varasi piispa Colliander. Seuraavina istui vähän pienempiä herroja. Löfströmille heltisi vasta viides tuoli ylipäällikön vasemmalta puolelta.

Tarjoilu alkoi valkoviinillä ja jatkui samppanjalla - Viipurin parhaat ravintolat todella osasivat kätkeä kalleutensa tai hankkia niitä mahdottomina aikoina mahdottomista paikoista. 
Tilaisuus ei luontunut pitkiin puheisiin. Mannerheim kiitti viipurilaisia muutamalla lauseella punavallan ikeen kestämisestä ja sitten taistelun voittajia, erityisesti jääkäreitä. Löfström odotti nimensä mainitsemista ja jatkoa, joita ei tullut. Vaatiko etiketti Itäarmeijan komentajan vastausta? Kukaan ei tuntunut sitä kaipaavan.

Ylipäällikkö ei millään lailla ilmaissut toivovansa Itäarmeijan komentajan vastausta, mutta kahvivaiheessa Löfström kilisti lasia. Hänen puheensa ei ollut pitkä eikä itsekeskeinen. Se loppui "yhdeksänkertaiseen suomalaiseen hurraahan" lähimmille alaisille. Sali raikui toistoista vähän vaivautuneesti. Löfström tyhjensi lasinsa ja asetti sen pöydälle. Ja käveli ulos, kauas pois juhlahumusta, rautatieasemalle omaan vaunuunsa.

Mannerheim kai yrmisteli ja puisteli päätään, muttei sanonut mitään. Eleistä lähti kiertämään railakkaampi juttu. Löfström oli käyttäytynyt julkeasti ylipäällikköä kohtaan ja skoolattaessa pirstonut maljansa. Tämä sapetti Löfströmiä, joka ei ollut eläessään särkenyt lasin lasia tahallaan eikä vahingossa.

Kai Donnerin 1930-luvulla tekemät julkaisemattomat haastattelut osoittavat, että Mannerheim koki alaisensa esille kohottautumisen kolossaalisena kurinrikkomisena (kolossalt disciplinsbrott). Puhe huipensi operaatiossa osoitetun omavaltaisuuden. Löfströmin olisi pitänyt käsittää etiketti tsaarinarmeijan perinteestä, Mannerheim sanoi, huuma vei arvostelukyvyn. Toisaalta kyse oli siitä, että Löfström oli tehnyt tehtävänsä ja sai mennä. Sihvon korvikkeella ei ollut enää mitään käyttöä valkoisen Suomen uusissa asetelmissa, joissa Mannerheiminkin oli pian väistyttävä taemmas. ${ }^{12}$

\section{VÄÄRIN VALLATTU VIIPURI}

Kävellessään ulos Seurahuoneelta illalla 1. toukokuuta Löfström käveli ulos myös Suomen kansallisesta historiankirjoituksesta. Mannerheim ei antanut anteeksi tsaarinarmeijan kaunoja, "kolossaalista kurinrikkomista" ja etikettikiukuttelua. Löfströmin vanha "ystävä" Hannes Ignatius veteli naruista nöyryyttävissä järjestelyissä. Kaupunki tyhjeni Itäarmeijasta, jota Löfström ei saanut seurata. Mannerheimista ja Sihvosta tuli kansallissankareita, Wilkmanista sotaväen päällikkö, Löfströmistä linnoituskomendantti eli ei mikään. Hän yleni kenraaliluutnantiksi, mutta jäi vaille 1. luokan Vapaudenristiä, jonka sotilasarvoltaan alemmatkin saivat.

Kun Viipurissa vieraili saksalaisdivisioonan komentaja Rüdiger von der Goltz, Löfström hoiti pikkutarkasti kohteliaisuudet. Vieras ei vastannut niihin vaan juhla-aterian nautittuaan häipyi kaupungista jättämättä edes käyntikorttiaan. Löfström uskoi, että Mannerheim ja Ignatius olivat suunnitelleet tämänkin loukkauksen. 


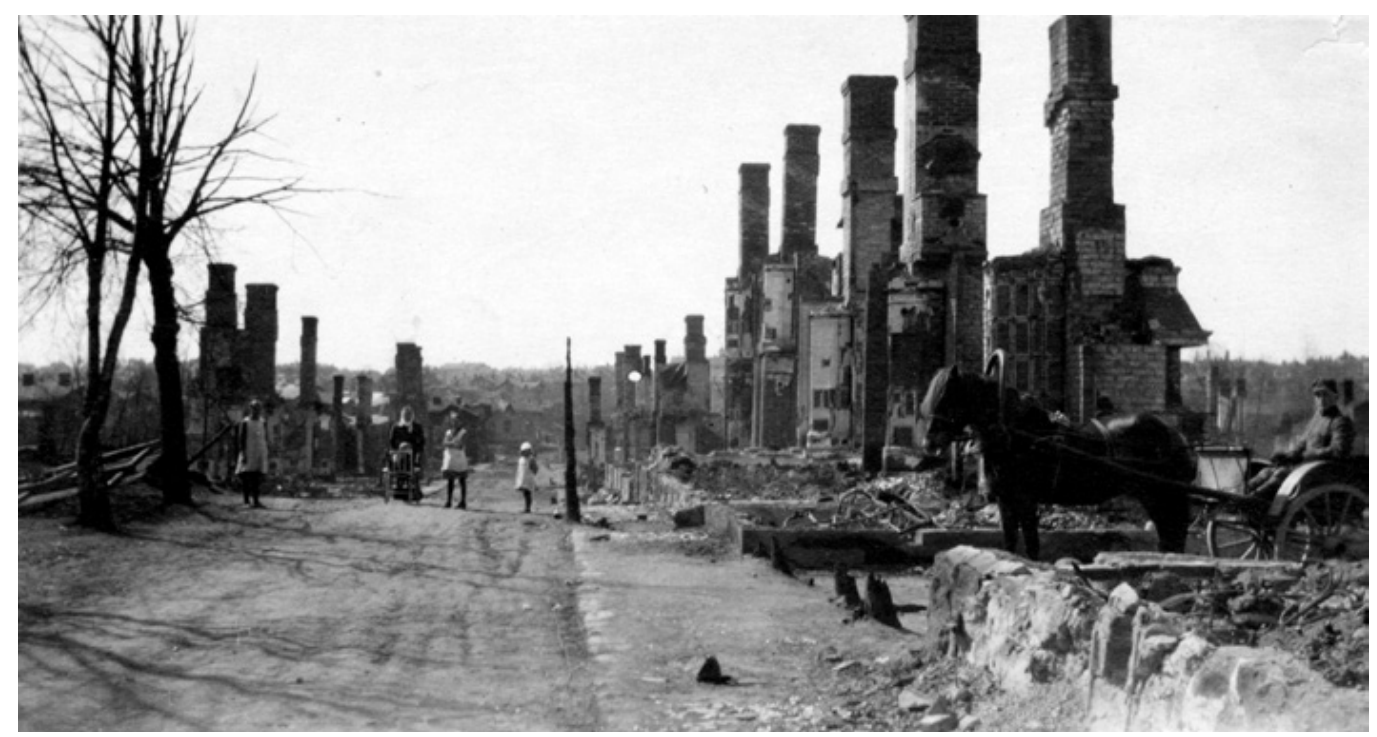

Lapsia Viipurin valtauksessa pahoin tuhoutuneen Kolikkoinmäen kaupunginosan raunioilla.

Kaiken pahan alun, Mannerheimin, itsekorostuksesta ja turhamaisuudesta kertyi Löfströmin mielestä typerryttäviä esimerkkejä. Kokenut 50-vuotias kenraali ja aatelismies huumaantui nyt rahvaan palvonnasta, vaikkei edes ymmärtänyt sitä suomen kielellä. Hänestä tuli narri, Löfström ajatteli. Suomi kouristeli nälänhädässä, kuljetuskalusto ei riittänyt elintarvikkeiden, kotiutettavien joukkojen saati punavankien käsittelyyn, mutta silti kaikkialta piti koota rekvisiittaa Helsingin suureen voitonparaatiin 16. toukokuuta 1918. Kansa nääntyköön, mutta Mannerheimia pitää juhlia! Aivan sama miten käy, kunhan jää huikaiseva vaikutelma hänen triumfistaan! Se ei ollut ainoastaan naurettavaa, kommentoi Löfström itsekseen, vaan myös rikollista. ${ }^{13}$

Löfströmin kohtelua sanottaisiin nykyisin työpaikkakiusaamiseksi. Hän koki, ettei häntä huolittu ja hyväksytty minnekään. Syrjitty Viipurin valloittaja näki melkein nälkää syksyllä 1918 ja oli joutua perheineen kadulle asunnostaan. Uran pituus ei lainkaan auttanut työnhaussa. Nyt nousivat Saksassa aliupseereina palvelleet poikaset majureiksi ja eversteiksi! Löfström vihasi Mannerheimia raha-asiankin vuoksi. Mannerheim joutui poliittisesti sivuraiteelle ja menetti valtansa, mutta sai kansalaiskeräyksestä miljoonia markkoja, jotka takasivat riippumattomuuden loppuelämäksi.

Viipurin valtaukselle koitti vuosipäivä toisensa jälkeen. Löfström kirjoitti omista ansioistaan kuivakan teoksen Ledningen av Östarméens opearationer $i$ Karelen 1918. Hän tahtoi rehabilitoida itsensä Viipurin valtaajana, mutta törmäsi vastarintaan. Sotahistorioitsija ja Sotakorkeakoulun opettaja J. O. Hannula huomasi heti perään tarpeelliseksi kirjoittaa julkaisun Itäarmeijan operaatioi- 
den suunnittelu ja johto v. 1918, jossa näkökulma oli nimien yhdenmukaisuudesta huolimatta aivan toinen, Mannerheimia kunnioittava.

Johtiko Itäarmeijaa tosiasiallisesti Löfström vai pysyivätkö langat ylipäällikkö Mannerheimin käsissä? Löfström löysi ymmärtäjiä nuoremmasta polvesta, joka katsoi Mannerheimin jalustan liian korkeaksi. Väittely levisi ammattikirjallisuuden ulkopuolelle ja sapetti Mannerheimia. Yksityiskirjeessä hän ihmetteli, miksi sanomalehdet "antavat nuorten, jotka vuonna 1918 kuolasivat ja kastelivat housujaan ja tekevät sen asiankäsittelytyylistään päätellen kaiketi vieläkin, laatia tuollaisia sotilaallista asiantuntemusta vaativia kirjoituksia!” Mannerheim jätti tästä pahastuneena väliin tammisunnuntain kunniaksi järjestetyt jokavuotiset upseeripäivälliset. Hänen oli vaikea ymmärtää myös "vanhojen miesten alentuvan kiivaasti hyökkäämään vuoden 1918 aseveljien kimppuun saadakseen arvostelukyvyttömältä yleisöltä enemmän tai vähemmän ansaitsemattoman sulan hattuunsa".

Viipurin taistelun kertauksen alarintamalla kävivät toistensa kimppuun Löfström ja Aarne Sihvo. Löfström arvosteli kirjoituksissaan Aarne Sihvoa verkkaisesta liikkeellelähdöstä, mistä jo Axel Rappe oli jankannut päissään vappuriehassa. Aarne Sihvo ei tietenkään niellyt nahjuksen leimaa. Hän syytti viiveestä Löfströmiä, joka 27. huhtikuuta oli kieltänyt lännestä "törmäämisen" hokemalla: "Ni få inte forcera. Kom ihåg! Ni få inte forcera!" Löfström puolestaan muisti sanoneensa: "Ni måste forcera". Rappe piti puolensa kirjoitellen artikkeleita lehtiin sekä kokoelma- ja yleisteoksiin ja esiintyi strategina ja esikunnan työmyyränä.

Yksi riita koski ylipäällikkö Mannerheimin piiritysrenkaalla käynnin ja Antrean kautta poistumisen ajoitusta 26. huhtikuuta 1918 paikkeilla. Päivämäärän ja tuntienkin tärkeys johtui siitä, että lennätin- ja telefooniyhteydet eivät kunnolla toimineet päämajasta Viipurin edustalle. Mikäli paikkansa piti muistikuva, jota Löfström todisteli 1930-luvulla arkistojen junanlähetyslistoista, Mannerheim häipyi liian aikaisin ja palasi liian myöhään voidakseen johtaa tai edes valvoa Viipurin kukistamista.

Löfström oli varmaan oikeassa siinä, että operaatio luiskahti Mannerheimin ulottumattomiin 27.-29. huhtikuuta. Se ei haitannut mitään, onnettomat punikit olisivat epäilemättä antautuneet jopa Rappen örinöiden mukaisesti. Tahtomattaan Löfström teki Mannerheimille palveluksen historiantutkimuksen tuomion edessä. Koska Mannerheim ei käytännössä johtanut valtausta, ei hän voinut vaikuttaa myöskään terrorin ensimmäiseen aaltoon ja yli 200 viattoman venäläisen ennätysteloitukseen.

Taistelu jälkimaineesta oli toivottoman epätasaista. Suuri yleisö muisti vapaussodasta Mannerheimin ja karjalaiset Sihvon. Niin olisi vastaisuudessakin. Ernst 
Löfström painui unhoon ja korkeintaan pahalla muistetuksi. ${ }^{14}$ Muistelmiinsa, joita ei tietenkään painettu, hän vuodatti punaleskien ja -orpojen tasoista katkeruutta. Viipurin valloitus vimmastutti, vihloi ja kalvoi häntä kai hautaan saakka. ${ }^{15}$

\section{Viitteet}

1 Viipurin valtauksen tapahtumat on kuvattu tarkasti: Keskisarja 2013.

2 KA: Ernst Löfströmin kokoelma, kansiot 1, 4 ja 7, Löfströmin päiväkirjat, muistelmakäsikirjoitukset ja muistiinpanot.

3 KA: Ernst Löfströmin kokoelma, kansiot 1, 4 ja 7, Löfströmin päiväkirjat, muistelmakäsikirjoitukset ja muistiinpanot. Urista tsaarinarmeijassa: Harjula 2014, 71, 96, 98, 102-103, 115, 130, 139, 159, 208, 226, 257, 261, 269-270, 273-277, 289 , 299, 308, 315-317, 326, 346, 418, 454, 464-465, 473.

4 Ignatiuksesta: Matti Lappalainen 2005, 277, 297.

5 KA: Ernst Löfströmin kokoelma, kansiot 1, 4 ja 7, Löfströmin päiväkirjat, muistelmakäsikirjoitukset ja muistiinpanot.

6 Komentajavaihdoksesta: Saarikoski 1998, 65-67; Lackman 2000, 596; KA: Päämaja 1918, kansio 17, Wärnhjelmin kirje Mannerheimille 16.2.1918.

7 KA: Ernst Löfströmin kokoelma, kansiot 1, 4 ja 7, Löfströmin päiväkirjat, muistelmakäsikirjoitukset ja muistiinpanot.

$8 \mathrm{KA}$ : Kai Donnerin kokoelma, kansio H3, Donnerin 1930-luvulla tekemät Mannerheim-haastattelut; KA: Ernst Löfströmin kokoelma, kansiot 1, 4 ja 7, Löfströmin päiväkirjat, muistelmakäsikirjoitukset ja muistiinpanot.

9 Keskisarja 2013, passim.

10 KA: Ernst Löfströmin kokoelma, kansiot 1, 4 ja 7, Löfströmin päiväkirjat, muistelmakäsikirjoitukset ja muistiinpanot.

11 KA: Siviilitoimituskunnan akti K.D. 113/58 1918; KA: Päämaja, kansio 16; Vapaussodan arkiston sähkekokoelma, kansio 595;
Ryhmä Wilkmanin esikunta, kansiot 2 ja 5; M. Tikka 2004 257-267; Westerlund 2004b, passim.

12 KA: Kai Donnerin kokoelma, kansio H3, Donnerin 1930-luvulla tekemät Mannerheim-haastattelut; KA: Ernst Löfströmin kokoelma, kansiot 1, 4 ja 7, Löfströmin päiväkirjat, muistelmakäsikirjoitukset ja muistiinpanot.

13 KA: Ernst Löfströmin kokoelma, kansiot 1, 4 ja 7, Löfströmin päiväkirjat, muistelmakäsikirjoitukset ja muistiinpanot.

14 Vaikka Löfström oli pettynyt kohteluunsa ja joutui kiistelemään jatkuvasti ansioistaan Viipurin valtaussuunnitelman laatijana, hänen upseerinuransa oli 1920-luvun mittakaavassakin varsin merkittävä. Jalkaväen tarkastajana (alun perin nimekkeenä oli Suomen armeijan tarkastava kenraali) hän osallistui itsenäisyyden alkuaikoina moniin komiteoihin, joissa suunniteltiin uuden valtion asevoimien varustamista ja aseistusta. Samoin hän sai laatiakseen Suomen armeijan ensimmäisen ampumaohjesäännön. Löfström ylennettiin vuonna 1927 jalkaväenkenraaliksi, joka oli korkein Suomessa rauhanaikana saavutettava sotilasarvo. Hän osallistui vuosina 1927-1928 myös puolustusneuvoston toimintaan. Hän erosi 63-vuotiaana vakinaisesta palveluksesta ja siirtyi eläkkeelle kirjoittamaan muistelmiaan. Löfström kuoli 71-vuotiaana vuonna 1937. Marjomaa 2005. (toim. huom.)

15 KA: Ernst Löfströmin kokoelma, kansiot 1, 4 ja 7, Löfströmin päiväkirjat, muistelmakäsikirjoitukset ja muistiinpanot; Keskisarja 2013, 355-372. 